\title{
Aid and Domestic Resource Mobilization with a focus on Sub-Saharan Africa
}

\author{
Oliver Morrissey \\ CREDIT and School of Economics, University of Nottingham
}

Accepted version of paper published in Oxford Review of Economic Policy, 2015, Vol 31 (3-4): 447-461 (DOI: 10.1093/oxrep/grv029)

\section{Acknowledgments}

This is an extensively revised version of a paper presented at the IMF-CFD Conference on Financing for Development, Geneva 15-17 April 2015. The author is grateful to participants, two anonymous referees, Chris Adam and David Vines for insightful comments, with the usual disclaimer.

\begin{abstract}
Increasing tax revenues in low income countries is essential to address future development finance requirements. This is particularly important for aid recipients, the focus of this paper. Theory shows that although there are many ways in which aid can have indirect effects on tax revenue, the direct effects arise because aid and tax are alternative sources of revenue and political economy factors influence the choices made by government. Aid may discourage tax effort if viewed as a politically less costly source of revenue. Under different conditions, the policies and reforms associated with aid may increase revenue, through promoting growth, encouraging more efficient tax structures or supporting reforms to tax administration. While cross-country evidence reveals no systematic pattern, country studies show that aid can be associated with administrative and efficiency reforms to increase tax revenue. The conclusion discusses how aid and donors can promote increasing domestic tax revenue.
\end{abstract}

Keywords: Aid, Taxation, Fiscal Response, Tax Reform 
JEL classification: F35, H20, O23 


\section{Aid and Domestic Resource Mobilization with a focus on Sub-Saharan} Africa

\section{Introduction}

As sustainable development targets are set to replace the Millennium Development Goals there is widespread recognition that increased financing will be required to meet development targets. Traditional sources of development finance, in particular aid, are unlikely to increase sufficiently to meet future needs. New sources of finance and leveraging the private sector offer promise, but these are uncertain and untested. It is important that developing countries increase the amount of their own funds available for development finance, i.e. domestic revenue mobilization (DRM), in particular increasing tax revenues (for a given growth rate, borrowing is only a temporary solution as future revenue must increase to service and repay debt). This is a major challenge for low-income countries (LICs) where revenue/GDP ratios have been relatively low for decades and are only increasing gradually. For example, in subSaharan Africa (SSA) in 2014 median domestic revenue was 18.5\% of GDP, an increase from $16.6 \%$ over 2004-08; this compares to median government expenditure of $28.2 \%$ and $21.9 \%$ respectively. For SSA LICs in 2014 mean domestic revenue was 16\% of GDP (13\% over 2004-08) compared to mean government expenditure of $22 \%$ and $21 \%$ respectively (IMF, 2015, pp. 82-3). There is wide variation within SSA as resource-rich countries have higher revenues (which include resource rents) whereas resource-poor countries that rely almost fully on taxes have lower revenues. ${ }^{1}$ As the majority of major aid recipients (as a share of GDP) and LICs are in SSA the paper focusses on SSA evidence although the issues are relevant to developing countries, especially LICs.

In broad terms there are three ways in which aid may have effects on tax revenue. At the most general level, as aid has macroeconomic effects and tax revenues are affected by macroeconomic performance, there can be indirect effects of aid on revenue. For example, if aid is effective in supporting growth revenue should increase in line with an expanding tax

\footnotetext{
${ }^{1}$ Excluding Nigeria, which tends to have relatively low revenue, six SSA oil exporters had on average a revenue/GDP ratio of $35 \%$ over $2004-08$ whereas the respective mean for middleincome SSA countries excluding South Africa was $21.7 \%$ and for SSA LICs was $13.2 \%$ (IMF, 2015, Table SA10, p. 82)
} 
base (although the tax/GDP ratio may not increase). Second, there may be direct fiscal effects: as most aid finances public goods and services it may substitute for efforts to raise tax revenue or, for a given level of tax, support a higher level of government spending. Such direct effects will be related to the amount of aid relative to the level of taxation. Finally, policies and conditions associated with aid (the broader donor-recipient relationship) can affect tax revenue. Support for tax administration or policy reform should increase revenue but other policy reforms may reduce revenue, at least in the short term (e.g. tariff reductions as part of trade reforms). In analyzing the relationship it is difficult to disentangle these various potential effects.

This paper assesses the literature on the effects of aid on tax revenue to identify lessons and implications for using aid to support and promote DRM. Political economy theory provides a conceptual framework linking taxation, as one element of policy that can be used to favour certain groups or interests, and aid (especially conditionality as this captures differences between objectives of donors and governments). This is outlined in Section 2. To focus discussion, attention is restricted largely to theoretical and empirical analysis of direct links between aid and taxation. Consequently, the large literatures on the macroeconomics of aid (such as general equilibrium models incorporating aid and tax), political economy of taxation and aid conditionality are only alluded to as conceptual background. The core issue is how aid and donors (i.e. conditions and policies associated with aid as distinct from the amount of aid) influence decisions on how much tax to raise and how to raise it. This literature identifies channels through which aid can affect taxation and factors to allow for in exploring the relationship. This literature does not provide the basis of empirical models for direct effects of aid on taxation but highlights the importance of political economy considerations affecting choices over tax and aid.

The theoretical foundations for empirical analysis of direct effects are derived from the pioneering study by Heller (1975) proposing fiscal response models (FRMs): in the budget determination process governments set targets for expenditure and revenue and utility is maximized by achieving the targets (this minimizes the political loss function on which the model is based). Aid received by the government is an additional source of revenue that is treated either as relaxing the budget constraint or altering the formation of targets (i.e. tax can be lower and/or spending can be higher than in the absence of aid). The fundamental issue is the fiscal response to aid - how does aid affect tax and spending outcomes (see Section 2.3)? The theory does not give a general prediction of the fiscal effects of aid: spending should 
increase but not necessarily fully by the amount of aid (although it may even increase by more than the aid); tax may be reduced, unchanged or even increased. In the FRM approach the fiscal effects of aid vary from country to country, reflecting weights attached to variables in the utility function that depend on underlying political and economic factors.

Section 3 reviews the empirical literature, distinguishing cross-country panel studies and FRM country studies applying time series methods. There is no consensus in the literature using cross-country regressions for the effect of aid on tax performance (measured as the revenue/GDP ratio): results are not robust to changes in sample or econometric modeling choice. Time series studies are informative on specific countries and suggest that tax is not responsive to aid, but they are no panacea; a relatively long time series is required and estimates are reliant on the quality of the data, which is often limited for LICs. Although there does not appear to be a systematic effect of aid on tax across countries the empirical evidence suggests conditions under which aid can support DRM.

Section 4 concludes by discussing how aid can be used to support reforms promoting domestic resource mobilization. The theoretical literature gives some guidance on which political and economic characteristics of countries are important for aid influencing tax and the empirical literature does show that it is not the simple amount of aid that matters. It can be inferred from the literature that the fundamental determinant of whether aid and donors can promote DRM is the willingness of the recipient to implement tax reforms. The evidence on tax reform is promising: significant reforms to tax structure have been implemented in many countries, increasing efficiency (of the tax system and collection) and reducing distortions (Keen and Mansour, 2010), in addition to improvements in tax administration (Moore, 2014). The policy implications discussed in the final section are the types of interventions that can help to improve tax performance and promote DRM.

\section{Conceptual Context: Choosing between Tax and Aid}

Aid recipients, especially LICs, face a situation where domestic revenue is too low to meet expenditure needs to provide the level of public goods required for growth and development; this is one reason why they receive aid and why it is often in the form of grants. The low domestic revenue does not imply that tax effort is weak, i.e. that tax/GDP ratios are particularly low and/or less than what could reasonably be achieved given the tax base and economic structure of such economies. Domestic revenue mobilization may be as high as is 
feasible (Keen and Simone, 2004) or even desirable, especially as LICs have tended to rely relatively heavily on highly distorting taxes on trade. Distortionary taxes are one example of the policy distortions analysed in political economy models illustrating that the potential for aid to have beneficial effects via taxation depends on the nature of the government and tax structure (Section 2.1). An alternative approach, set out in Section 2.2, views governments as choosing between aid and tax as alternative sources of revenue with attendant costs and benefits. The FRM approach formalises this as budgetary choices (Section 2.3).

\subsection{Political Economy Considerations}

Political economy analyses identify institutional failure in LICs arising because governments favour specific groups at the expense of the public, and this generates policy distortions (e.g. Bates, 1981). The outcome is a politics that is not conducive to growth, particularly pronounced in Africa (Azam, 2008; Bates, 2008). This literature is more concerned with distributional policies and political considerations influencing the choice between productive and non-productive expenditure, where the former refers to provision of public goods and services and the latter to transfers to favoured groups, than the choice between aid and tax. It is informative regarding how politics leads to policy distortions, corruption and rent-seeking that undermines growth, and provides the basic motivation for including political or institutional quality variables in cross-country regressions, but is rarely explicit about the relationship between aid and taxation.

Adam and O'Connell (1999) combine elements of macroeconomic and political economy theory to illustrate conditions under which aid may or may not reduce the adverse effects of distortionary taxation. Taxes, paid by all households, finance productive spending and transfers but are distortionary so higher taxes reduce the quality of investment and thus growth (one tax reform implication is to shift to less distortionary taxes). They present a model where the government is 'captured' by a group representing a proportion of the population, so that the government may be acting in the interests of a narrow elite or may have a more encompassing politics acting in the interests of the broader private sector as a whole. The introduction of aid into this system may shift the political equilibrium.

The mechanism in the model (represented by a parameter for the proportion of the population in whose interests the government acts) is that transfers paid for by distortionary, hence growth-reducing, taxation are consumed exclusively by the elite but the costs are spread 
across the economy as a whole. If the elite is small (low proportion of population) the gains to the elite from distortionary taxation (the higher consumption by the elite due to the transfers) outweigh the costs to them (because the costs of distortionary taxation are shared across the whole economy). The equilibrium is transfers to a narrow elite financed by growthreducing taxation. If the 'elite' becomes large enough it will be in the elite's interest to limit transfers because the cost to the broad elite of higher taxation outweighs the benefit of transfers spread across a large proportion of the population. This equilibrium developmental state with a broad 'encompassing interest' eschews transfers in favour of productive spending. Introducing unconditional aid may shift the encompassing interest point so that a developmental state reverts back to transfers to a narrow elite (Adam and O'Connell, 1999: 237).

There are a number of implications for analysis of the effects of aid on taxation. First, effects on the level of tax may not be important: if aid is used to reduce distortionary taxes it is likely to be beneficial even if tax/GDP ratios are lower. Thus tax policies promoted by donors to reduce distortions, such as reducing tariffs and replacing with VAT or supporting administrative reforms, may be more important than effects on the level of tax. Second, to the extent that the objective of aid is to support growth the composition of spending, in particular the level of productive spending, is as important as the level of tax. This is consistent with the fiscal response approach. Third, conditional aid is the mechanism through which donors attempt to address institutional failures or distortionary politics, but how this may affect the political equilibrium is complex (Adam and O'Connell, 1999: 242-3). In the fiscal context the relevant conditions relate to tax and expenditure composition (in the context of budget support see Clist et al, 2012), and relevant policy implications include tax structure and administrative reforms (discussed in Section 4).

\subsection{Political Calculus}

A dimension that has not attracted explicit attention in this literature is that the recipient government may perceive political costs and benefits of aid and taxation as alternative sources of revenue so there is a trade-off - a political calculus between aid and tax where each is evaluated according to autonomy and accountability and bureaucratic costs (Morrissey and Torrance, 2015). A government that values autonomy and wants to be less aid dependent will choose more tax effort. As donor agencies have to account for their aid spending, donors place increasing emphasis on measures to monitor the use of aid, minimise fungible use and 
tackle corruption. The policy reform conditions and technical assistance associated with aid increase the political costs of aid as some control and influence is ceded to donors. More effort has to be made to account to donors for how aid is used than to account to taxpayers for how taxes are raised or spent. The latter will depend on the nature of the democracy, which is typically weak in LICs, at least for accountability to taxpayers.

The requirements of accounting to donors and negotiating on conditionality reduce the autonomy of aid recipients by limiting their policy discretion; even limited conditionality is a constraint on policy action (if only because effort has to be expended to avoid or circumvent the conditions). Governments can be expected to prefer greater autonomy (being seen as subject to foreign influences can undermine domestic popularity so aid dependence is a political cost). Increasing taxes may impose a cost of being more accountable to domestic constituencies but this is unlikely to offset the benefits of autonomy; indeed, DRM with accountability can play an important role in supporting State building and legitimacy (Moore, 2008; 2014). Countries with access to resource rents may have less incentive to increase taxes: Altincekic and Bearce (2014) argue that because aid is subject to conditionality and less fungible than resource (oil) revenues governments are more likely to raise domestic resource revenues than aid if they want control over how revenues are used. The accountability costs of aid, given donor monitoring and perception of external influence on policy, are likely to be higher than for taxation so it should not be assumed that governments always prefer aid to tax, or indeed that they would substitute aid for tax (as noted above, it is beneficial to substitute aid for distortionary taxes). The political calculus may favour taxation to support autonomy.

The administrative costs of tax should be offset against bureaucratic costs of aid, such as the costs of numerous officials meeting with and reporting to donors. As recipients face many donors with more and changing requirements on monitoring aid delivered in different ways for multiple purposes, aid costs remain high. The trend in bureaucratic costs is likely to favour taxes over aid, given emphasis on improving public finance management (PFM) and encouraging anti-corruption measures. Even if PFM and tax administration reforms are difficult to implement effectively to achieve sustained improvements (Andrews, 2013) there have been significant achievements in tax administration and fiscal reforms (Moore, 2014) that reduce the bureaucratic costs of taxation. Ahlerup et al (2015) provide evidence that semiautonomous revenue authorities in SSA have been associated with increased tax collection for given tax rates, at least in the short term (the effect tends to plateau after about five years). 
The merit of such revenue authorities, now in place in some 15 SSA countries (mostly Eastern and Southern Africa), is that collecting taxes is sub-contracted to the independent agency (which receives performance incentives). The weakness is that government (politicians) retain control over tax policy, especially granting exemptions (so they can still favour selected groups, although in a less distortionary manner than in standard political economy models).

Governments may be most amenable to aid when they view it as a resource to which they have (personal) access; arguments such as this lie at the root of theoretical papers on aid conditionality failure (e.g. Svensson, 2003). Thus, when aid is given to corrupt autocratic regimes one would not be surprised if tax collection was relatively low. This is a problem of the particular donor-recipient relationship rather than the effect of an amount of aid on tax effort (in another country the same amount of aid could be used effectively). Weak governance, rent seeking and corruption are all typical features of LICs that help to explain their poor economic performance, hence they receive aid. Corruption and rent seeking can also help explain relatively low tax collection, as exemptions are pervasive and evasion is undetected or not punished. Whether aid affects corruption is a separate question that is not easy to address. It is reasonable to posit that corrupt individuals are most concerned with easy money, i.e. less transparent transactions are more attractive because the corrupt wish to minimise the possibility of being observed. On this basis aid is least attractive because it is subject to greater monitoring by donors; corruption involving donor funds is more likely to be observed and investigated (the only claim is less, not no, corruption). Donor technical support and institutional interventions for monitoring tax and public expenditure are intended to reduce corruption in public finance, but may be most effective for aid funds. Thus there are circumstances under which the political calculus could favour taxation over aid, at least at the margin, and these are more likely to apply under better governance and fiscal institutions.

\subsection{Fiscal Response}

Heller (1975) introduced fiscal response models (FRMs) where utility for the 'public decision makers' is represented by:

$$
U=F\left[I g, T, G_{C}, G_{S}, B\right]
$$

Public sector policymakers are assumed to act in a rational, utility-maximizing manner where (1) is represented as a loss function such that utility is reduced to the extent that the targets (determined in the budgetary process) are not achieved for, respectively, public investment, 
tax revenue, civil consumption spending, socioeconomic government spending and borrowing. Governments maximize their utility by attaining their revenue and expenditure targets. Heller (1975, p. 430) recognized that aid affects the decisions although it was not included in the utility function for (1) but instead entered as an inflow that relaxed the budget constraint. Franco-Rodriquez et al (1998) incorporated aid directly into the utility function so that targets for aid were included along with other fiscal targets. Specific predictions for the effect of aid could be made if explicit weights were attached to the variables in the utility function (corresponding to an assessment of the costs and benefits of variables as discussed in Section 2.2) but the literature treats these as parameters to be estimated.

Although assuming that donors intend that aid is allocated to investment spending, Heller (1975, p. 433) acknowledged that fungible aid would be apportioned between government investment $(I g)$ and consumption $\left(G_{C}, G_{S}\right)$ spending. The model was estimated for 11 African countries using annual data for the 1960s, and suggested that aid supports increased investment spending and, although there appeared to be some reduction in taxes, 'the reduction in public fiscal effort is primarily focussed on reduced borrowing than reduced taxation' (Heller, 1975, p. 442). McGillivray and Morrissey (2004) review the FRM literature and note that results for tax effects vary, as may be expected. Section 3.2 reviews recent FRM country studies applying time series methods.

\section{Aid and Revenue: Empirical Evidence}

The empirical literature addressing specifically the effect of aid on tax revenue is not extensive and falls into one of two types, cross-country regressions including aid among the determinants of the revenue/GDP ratio (most studies use the total, i.e. tax and non-tax revenue) and studies estimating FRMs (mostly for individual countries). Both derive the theoretical motivation from Heller (1975), albeit loosely in the former (the specification is a standard tax performance equation augmented with aid), as providing the framework in which aid received by the government can alter choices on other fiscal variables, specifically revenue in the former (most FRM studies focus more on effects on spending). Political economy factors are not explicitly included, except insofar as some cross-country studies control for institutional quality and country studies refer to the political economy context as part of the narrative (but do not include institutional variables in the analysis). These literatures are discussed in turn. 


\subsection{Cross-Country Panel Evidence}

Although motivated by the underlying budget identity (Gupta et al, 2004, pp. 388-9), the specification employed in cross-country regressions is a representation of the contemporaneous tax performance relationship. In principle, if one had detailed information on the composition of each tax base, such as incomes and consumption spending, tax revenue can be calculated as the sum of the tax rates applied to respective tax bases. In practice such detail is not available so proxy variables are used to capture the base. Typically shares of agriculture, industry and trade in GDP are employed. The agriculture share is intended to capture the tendency for the large agriculture sector in LICs to be primarily subsistence, hence generating low revenue because subsistence farmers (and the informal sector more generally) have low incomes that are difficult to tax directly (the expected coefficient is negative). Commercial agriculture is captured through agri-business (in industry) or exports (in trade). The coefficient on industry is expected to be positive as this variable captures the level of production activity that is more likely to be taxed (through incomes, profits or consumption spending). Trade is expected to be particularly important given the historic reliance on tariffs and export taxes. It also relates to political economy factors both because these were often the most distortionary taxes and have been significantly reduced over time.

The recent cross-country literature on the effect of aid on tax performance is based on estimating a model following Gupta et al (2004, p. 391), for country $i$ in period $t$.

$$
\ln R_{i t}=\beta_{0}+\beta_{1} A G R_{i t}+\beta_{2} I N D_{i t}+\beta_{3} T V_{i t}+\beta_{4} Y_{i t}+\beta_{5} F_{i t}+\beta_{6} L_{i t}+\varepsilon_{i t}
$$

The dependent variable, $R$, is the ratio of domestic revenue to GDP; the log transformation is used because this non-negative variable is positively skewed. Tax revenue alone is rarely used; instead total revenue comprises taxes plus non-tax revenue (NTR, primarily revenues from resource extraction, often termed resource rents). Aid is disaggregated into grants $(F)$ and net loans $(L)$, net aid in total is also used (all as ratios of GDP) and sometimes aid-squared terms are included. The share of agriculture (AGR), industry (IND) and trade (TV), the trade volume measure of imports $(M)$ plus exports $(X),{ }^{2}$ in GDP are proxy measures of the tax base; revenue is expected to be decreasing in $A G R$ and

\footnotetext{
${ }^{2}$ Clist and Morrissey (2011) include $X$ and $M$ separately in place of TV on the basis that tariffs and export taxes have been reduced at different times and degrees whilst exports may capture the revenue impact of increased activity in cash crop and resource sectors.
} 
increasing in IND and trade. GDP per capita $(Y)$ captures the level of development (ceteris paribus associated with greater tax collection efficiency so higher revenues).

The analyst faces three challenges in estimating (2): measuring revenue; dealing with endogeneity; and accounting for heterogeneity. Regarding the first, Gupta et al (2004), Clist and Morrissey (2011), Benedek et al (2012) and Carter (2013) uses IMF data on total revenue (but the samples are not identical). Morrissey and Torrance (2015) use tax revenue (that excludes resource revenues placed in the NTR category) from the Government Revenue Dataset (GRD) compiled by the International Centre for Tax and Development (ICTD). The GRD provides data on total government revenue, breaks this down by tax headings insofar as possible, and distinguishes total tax revenue and NTR for the period 1970-2010 (Prichard et al, 2014). As the IMF and GRD sources yield different samples and no study has compared both for identical samples it is difficult to know how much of the variation in results is due to measurement differences (but neither source gives robust results).

There is simultaneity between aid and tax: poor countries that receive more aid (and for whom it is more likely to be in the form of grants) are also likely to have low tax ratios. While controls capture this to some extent, there may be within variation (differences in countries over time) related to these characteristics. For example, to the extent that aid increases in response to negative shocks (Lensink and Morrissey, 2001) that may also reduce tax revenue, the negative correlation can be observed within for some countries (those most vulnerable to shocks). Studies of aid and tax employ internal instruments to address endogeneity and results are sensitive to the approach taken. In principle, aid could be instrumented adopting approaches used in aid-growth studies but such instruments are usually weak (see discussion in Dreher and Lohmann, 2015) and have not been employed in this literature.

Gupta et al (2004) lag aid one period (i.e. one year) and report a negative effect of grants and positive effect of loans on tax. Clist and Morrissey (2011) adopt longer lags for aid on the basis that, following FRMs, tax effort (target revenue) is an outcome of the budget process hence influenced by expectations of aid (for which historic aid is a proxy); changes in aid would take time to alter expectations and hence to affect tax effort. While the use of lags alone does not identify the effect of aid the significance of the aid coefficient disappears with longer lags (the country time series studies cited below find no evidence that tax responds to aid). Morrissey and Torrance (2015) use GRD and tax revenue; although they can replicate the results of Gupta et al (2004) for pooled OLS, results are not robust for other estimators or 
including alternative control variables; generally the coefficients on aid variables become insignificant (and when significant are more often positive).

Benedek et al (2012) employ a Generalised Method of Moments (GMM) estimator and claim that the negative effect of grants on tax effort is a robust result. While GMM estimators can address endogeneity under certain conditions, Carter (2013) argues that the required conditions are unlikely to be met in the current context and shows using more flexible econometric techniques (panel time series and group fixed effects estimators) that the previous result are not robust. Clist (2014) observes that the problem of artificial changes in revenue (due solely to changing the data source) from combining data from different sources are built in to the internal instruments used in GMM so the results in Benedek et al (2012) may not be as reliable as claimed. A comparison of results from the studies covered here show that findings of a negative or positive effect of aid on revenue are not robust. One is likely to observe a negative association between aid, especially grants, and revenue, especially for the 1970s and 1980s, but there is no solid basis to infer causality. The negative association is less likely to be observed after the 1980s or for countries with relatively better institutional quality.

Heterogeneity is a plausible reason for the absence of robust results as very different types of countries are included, such as LICs, transition economies and upper middle income countries with negligible aid receipts. Cross-country aid-growth regressions face the same challenge: as each recipient has distinct characteristics and different factors that interact to affect growth performance the dynamic relationship between aid and growth is specific to each country (Herzer and Morrissey, 2013). Similarly, the determinants of tax revenues and how they are affected by aid vary across and within countries, and of course the central determinant of this is how political economy factors play out in each country.

An inherent limitation of cross-country tax ratio regressions is that the important country-level determinants of revenue are not adequately captured by available data. The results are indicative on how tax ratios vary broadly according to changes in economic structure and income levels. The results are less informative on the effects of aid on tax as the approach does not identify the ways in which aid affects tax. The effect of aid on taxation depends more on technical assistance and policy reforms associated with aid than on the amount of aid. Such policies or conditionality can affect the tax base or rates or overall collection efficiency through tax administration reforms, but studies do not capture any relationship between aid and tax policy reforms. Some reforms associated with aid conditionality may reduce tax revenue in the short term yet promote increased revenues in the 
longer term. The immediate effect of trade liberalisation is a reduction in tariffs so, for given import levels, revenues fall initially (Aizenman and Jinjarak, 2009). However, tariffs are distortionary so fewer and lower tariffs discourage avoidance and evasion and the reduced price distortions and economic efficiency encouraged by liberalisation may increase the level of imports so tariff revenues can increase. The principal limitation of cross-country studies is the failure to incorporate differences in reform efforts at the country level.

\subsection{Aid and Tax from a country perspective}

Countries have implemented tax and related reforms in different ways, at varying speeds and intensities, and with different degrees of support from donors or influence of aid conditionality. Consequently, it is reasonable to expect effects on tax revenues will vary across countries; it is very unlikely that any relationship between aid and revenue would be similar across the variety of LICs. Although the amount of aid allocated specifically to support tax and fiscal reforms is quite small, donors and technical support have influenced the pattern of reform (for the case of tariff reforms see Jones et al, 2011). The potential effects of the amount of aid on tax effort have been addressed in FRM studies of the fiscal effects of aid which examine the relationships between domestic revenue, government spending and aid as a fiscal system (Section 2.3 above).

There are relatively few country studies using time series methods, and few explicitly focus on the effect on taxation. In the first study of this type, Osei et al (2005) for Ghana over 1966-1998 found that aid was associated with increased tax revenue. This was not an effect of the amount of aid on tax effort but because of successful reforms in the 1980s associated with aid conditionality, especially in the cocoa sector, that increased economic activity and therefore supported a rise in tax revenue. They also found that the increase in aid was used to reduce domestic borrowing, again because of conditionality. In this case it was policy conditions not the amount of aid that affected tax revenue. Morrissey et al (2007), using data for Kenya over 1964-2002, found no evidence that aid grants adjusted to or influenced tax revenue, or even that tax was an adjusting variable (tax did not appear to adjust to fiscal disequilibria); aid loans responded to budget deficits so although they did not influence tax revenue they may have adjusted to revenue shortfalls. In the Kenyan case also the amount of aid did not affect tax revenue. 
More recent studies of the fiscal effects of aid adopt cointegrated vector autoregressive (CVAR) time series methods that allow estimates of which variables drive the system and how the variables respond to each other following the methodology of Juselius (2006). This method is quite useful as one can in principle distinguish whether or not tax adjusts to aid (this would be required to demonstrate that aid influences tax effort), as the testing methodology allows one to distinguish the cointegration relations (pulling forces) from the stochastic trends (pushing forces) and to test for purely adjusting variables (completely endogenous in the system), the shocks to which have only transitory effects. Bwire et al (2015) analyse the relationship between foreign aid and domestic fiscal variables in Uganda over the period 1972-2008 using this CVAR method. The results show that aid is a pushing force in the system associated with increased tax revenue and public spending. Tax revenue is not an adjusting variable although it does respond (positively) to aid, and shocks to tax have only transitory effects.

Mascagni and Timmis (2014), using CVAR with government data for Ethiopia over 1960-2009, find that aid (grants and loans) is positively related to tax revenue. There is no evidence that tax adjusts to aid (i.e. aid is not driving tax); rather, as aid is an adjusting variable in the fiscal system the finding suggests that donors rewarded Ethiopia when it increased domestic revenue (they also seemed to reward development spending). As above, it is the relationship with donors rather than the amount of aid that mattered. 'This relation may be explained by a beneficial effect of aid in improving tax policies and strengthening the tax administration. Indeed, throughout the whole period the government of Ethiopia has received foreign advice on tax matters, and this remains one of the policy areas of highest agreement between the government and donors today' (Mascagni and Timmis, 2014, p35). Martins (2010), using CVAR for quarterly data for Ethiopia over 1993-2008, also finds that aid responds to development spending, but finds no evidence that aid affects tax revenue (perhaps because quarterly data is not appropriate to capture tax policy responses). Although relevant studies only cover Ethiopia, Ghana, Kenya and Uganda, there is no evidence that aid reduces tax revenue, in some cases it supports increases in tax revenue and the conditions or policies associated with aid appear more important for tax than the amount of aid.

\section{Conclusion: Aid Support for Domestic Revenue}

The empirical evidence may appear to show that grants reduce tax effort but this could be simple correlation: LICs have a low tax base and relatively low revenue but receive aid (grants) 
because they are poor, hence the observed correlation between high aid and low tax. Results are sensitive to specification, estimation method, data and sample. Theoretical considerations show that any effect of aid on tax reflects a revenue choice that will vary across countries depending on political economy factors; ultimately it is a political choice, which donors may influence through support and conditionality, over which source of revenue best meets government objectives (and in practice they may be making choices for changes at the margin). Econometric specifications in aid-taxation studies have not adequately accounted for policy changes, whether in tax rates or administration (that may be influenced by donors), but may capture indirect effects of aid, such as through growth in a tax base. Donor-supported policy reforms and technical assistance, such as in tax administration and public finance management, may have a greater effect on tax performance than the actual amount of aid. ${ }^{3}$ The policy reforms and leverage associated with aid have had effects on improving PFM and tax administration, shifting the political calculus away from relying on aid towards taxation.

Donors can use aid to leverage DRM by providing technical assistance and policy support for reforms that reduce the costs of taxation and encourage recipients to view effective DRM as promoting fiscal autonomy; where recipients are receptive, donors could also note that DRM supports accountability and State building. Encouraging the establishment of semi-autonomous revenue authorities is one innovation that has been found to increase tax revenue. An especially promising initiative is the Tax Administration Diagnostic Analysis Tool (TADAT) being developed by the IMF in collaboration with a variety of partners (see TADAT under www.imf.org) as this allows institutional reforms to be tailored to the characteristics and administrative needs of individual countries. This approach can identify the weaknesses in the system and prioritise the order in which issues need to be addressed to improve tax administration and promote DRM.

The TADAT approach identifies nine performance outcome areas (with dimensions and indicators for detailed analysis within each). The basic area is integrity of the tax base: do the authorities know who should pay tax, is the register up to date and are there mechanisms to ensure those who should register do so. Risk management relates to identifying and monitoring compliance; there are also areas on voluntary compliance (provision of clear information and perceptions of taxpayers), filing tax returns (monitoring that those liable for tax file on time), payment obligations (monitoring that the correct tax liability is paid on time)

\footnotetext{
${ }^{3}$ Many tax performance studies include tax policy reforms (e.g. Ahlerup et al, 2015) but do not include aid.
} 
and ensuring accuracy of reporting (including auditing of returns). The other areas relate to administration: dispute resolution (fair and timely), operational efficiency (taxes are collected effectively and on time) and accountability (internal and external controls to ensure integrity of collection is perceived by taxpayers).

The merit of TADAT is the forensic approach to addressing performance of the entire system, from the register of taxpayers to compliance, auditing, dispute settlement and overall transparency. This can be useful in identifying where the problems lie. For example, if revenue is below expectations is it because some taxpayers avoid registering (revealed by the integrity of the tax base) or those who are registered are not paying in full (identified through risk management and payment obligations); in practice it may be a combination of both but the diagnostic analysis allows authorities to assess which areas should be given priority. The answer to such a question informs the appropriate response. For example, if the main shortfall is due to compliance it could be because taxpayers are not well informed about what they should pay (addressed through improving mechanisms for voluntary compliance), because monitoring of accuracy of reporting is weak (can be addressed within the authority) or because there are avoidance opportunities (which may need to be addressed through legislation, such as eliminating loopholes or exemptions).

Specific reforms or initiatives, such as adopting new technology to improve operational efficiency, can be assessed within this broad framework. To increase VAT collection rates, the Ethiopian Revenue and Customs Authority (ERCA) phased in the use of electronic sales register machines over 2008-2013 to register transactions by businesses for VAT. In principle this allows the ERCA to receive data on reported revenues and VAT liabilities on a daily basis and to monitor reporting patterns; 'unusual activity' such as fewer transactions than would be expected for the business can be identified and visits by officials can be targeted. This improvement in risk management and monitoring payment obligations is estimated to have increased VAT revenue by up to 20 per cent (Ali et al, 2015). However, as only registered businesses are required to use the machines, sustained effectiveness relies on the integrity of the register and businesses could evade by closing down and re-emerging in the informal sector. Ethiopia has a competent, semi-autonomous, ERCA and maintains an industrial census so the register is accurate by SSA standards, and tax collection is relatively good. The technology may not be as effective in other LICs with weaker capacity, but TADAT provides a method to assess the needs and weakness of any country and identify where aid-financed technical support should be targeted. 
Aid amounts are likely to influence fiscal behaviour, including taxation, insofar as the aid is revenue to the government and therefore included in budgeting decisions, but any such effects can vary from country to country. Fiscal responses to aid are likely to vary according to the importance of aid in the budget and the government's preferences and fiscal space over spending and other sources of revenue (tax, non-tax and borrowing). Country studies of the fiscal effects of aid suggest they tend to be positive; although there is a negative association between aid and tax across countries, improvements in technical support and tax policy advice from donors promote sustainable increases in tax revenue when they can work with government.

Policies associated with aid are likely to be more important than the amount of aid for promoting domestic revenue mobilization, and in particular increases in tax revenue. Countries that show willingness to increase tax effort, where aid is associated with or has rewarded increasing tax revenue, are the most amenable to continued donor leverage, but donors can influence reform in other countries. Aid can play a number of roles, such as supporting costs of reform (e.g. compensating for temporary losses of revenue when taxes are reformed, such as reducing tariffs); financing technical assistance to implement reforms (such as in tax administration); and supporting donor-recipient dialogue to promote administrative and institutional reforms. Institutional reforms are difficult to implement and sustain because they are deep, in the sense that they impinge on the behaviour (and incentives) for politicians and officials. Donors can be most effective by altering preferences, demonstrating the benefits to government autonomy associated with reducing reliance on aid relative to taxes and showing that increasing tax revenues mobilizes domestic resources in addition to encouraging accountability that can underpin building State legitimacy. This will be most difficult where the incentive to increase taxes is least, such as where the political economy constellation is unfavourable or governments have access to significant resource rents; it will be most effective where donors deploy aid to support government initiatives in tax administration and collection reform.

\section{References}

Adam, C. and S. O'Connell (1999), Aid, Taxation and Development in Sub-Saharan Africa, Economics and Politics, 11, 225-253

Ahlerup, P., T. Baskaran and A. Bigsten (2015), Tax innovations and Public Revenues in SubSaharan Africa, Journal of Development Studies, 51 (6), 689-706 
Aizenman, J. and Y. Jinjarak (2009), Globalisation and Developing Countries - a Shrinking Tax Base, Journal of Development Studies, 45 (5), 653-71.

Ali, M., A. Shifa, A. Shimeles and F. Woldeyes (2015), Information Technology and Fiscal Capacity in a Developing Country: Evidence from Ethiopia, IDS, Brighton: International Centre for Taxation and Development (ICTD), ICTD Working Paper 34 (www.ictd.ac).

Altincekic, C. and D. Bearce (2014), Why there Should be No Political Foreign Aid Curse, World Development, 64, 18-32.

Andrews, M. (2013), The Limits of Institutional Reform in Development, Cambridge, UK: Cambridge University Press.

Azam, J-P. (2008), The Political Geography of Redistribution, Chapter 6 in B. Ndulu, S, O'Connell. R. Bates, P. Coller and C. Soludo (eds), The Political Economy of Economic Growth in Africa 1960-2000, Volume 1, Cambridge: Cambridge University Press, pp 225-248

Bates, R. H (1981), Markets and States in Tropical Africa: the Political Bias of Agricultural Policies, Berkeley: University of California Press

Bates, R. H. (2008), Domestic Interests and Control Regimes, Chapter 4 in in B. Ndulu, S, O'Connell. R. Bates, P. Coller and C. Soludo (eds), The Political Economy of Economic Growth in Africa 1960-2000, Volume 1, Cambridge: Cambridge University Press, pp 175-201

Benedek, D., E. Crivelli, S. Gupta and P. Muthoora (2012), Foreign Aid and Revenue: Still a Crowding Out Effect? IMF, Washington DC: IMF Working Paper WP/12/86.

Bwire, T., O. Morrissey and T. Lloyd (2013), A Time Series Analysis of the Impact of Foreign Aid on Central Government's Fiscal Budget in Uganda, World Institute of Development Economics Research (WIDER), Helsinki: WIDER Working Paper No. 2013/101

Carter, P. (2013), Does Foreign Aid Displace Domestic Taxation? Journal of Globalization and Development, 4, 1-47.

Clist, P (2014), Foreign Aid and Domestic Taxation: Multiple Sources, One Conclusion, IDS, Brighton: International Centre for Taxation and Development (ICTD), ICTD Working Paper 20 (www.ictd.ac).

Clist, P., Isopi, A. \& Morrissey, O. (2012), Selectivity on Aid Modality: Determinants of Budget Support from Multilateral Donors. Review of International Organizations, 7, 267-284.

Clist, P. and O. Morrissey (2011), Aid and Tax Revenue: Signs of a Positive Effect since the 1980s. Journal of International Development 23, 165-180.

Dreher, A. and S. Lohmann (2015), Aid and Growth at the Regional Level, paper presented at the IMF-CFD Conference on Financing for Development, Geneva 15-17 April 2015.

Franco-Rodriguez, S., M. McGillivray, and O. Morrissey (1998), 'Aid and Public Sector in Pakistan', World Development, 26, 1241-50.

Gupta, S, B Clemens, A Pivovarsky, and E Tiongson. (2004), Foreign Aid and Revenue Response: Does the Composition of Aid Matter? in S. Gupta, B. Clemens and G. Inchauste (eds) Helping Countries Develop: The Role of Fiscal Policy, Washington DC: IMF (chapter 14, pp. 385-406).

Heller, P. S. (1975), A Model of Public Fiscal Behaviour in Developing Countries: Aid, Investment and Taxation, American Economic Review, 65, 429-45.

Herzer, D. and O. Morrissey (2013), Aid and Domestic Output in the Long Run, Review of World Economics, 149, 723-748. 
IMF (2015), Regional Economic Outlook: Sub-Saharan Africa, Navigating Headwinds (April 2015), Washington DC: International Monetary Fund.

Jones, C., O. Morrissey and D. Nelson (2011), Did the World Bank Drive Tariff Reforms in Eastern Africa?, World Development, 39 (3), 324-335

Juselius, K. (2006), The Cointegrated VAR Model: Methodology and Applications, Oxford: Oxford University Press.

Keen, M. and A. Simone (2004), 'Tax Policy in Developing Countries: Some Lessons from the 1990s and Some Challenges Ahead', chapter 12 in Gupta S, Clements B, Inchauste G. (eds), Helping Countries Develop: The Role of Fiscal Policy, Washington DC: International Monetary Fund, pp. 302-352.

Keen, M., and M. Mansour (2010), Revenue Mobilisation in Sub-Saharan Africa: Challenges from Globalisation I - Trade Reform, Development Policy Review, 28, 553-571

Lensink, R. and O. Morrissey (2000), Aid Instability as a Measure of Uncertainty and the Positive Impact of Aid on Growth, Journal of Development Studies, 36:3, 30-48

McGillivray, M., and O. Morrissey (2004), Fiscal Effects of Aid, in T. Addison and A. Roe (eds), Fiscal Policy for Development, Basingstoke: Palgrave Macmillan/WIDER, pp. 72-96.

Martins, P. (2010), Fiscal Dynamics in Ethiopia: A Cointegrated VAR Model with Quarterly Data, University of Nottingham, School of Economics: CREDIT Research Paper 10/05

Mascagni, G. and E. Timmis (2014), Fiscal Effects of Aid in Ethiopia: Evidence from CVAR applications, University of Nottingham, School of Economics: CREDIT Research Paper $14 / 06$

Moore, M. (2008), Between Coercion and Contract: Competing Narratives on Taxation and Governance. Taxation and State Building in Developing Countries: Capacity and Consent, in D. Brautigam, O-H. Fjeldstad and M. Moore (Eds), Cambridge: Cambridge University Press, pp. 34-63.

Moore, M. (2014), Revenue Reform and Statebuilding in Anglophone Africa, World Development, 60, 99-112.

Morrissey, O., D. M'Amanja and T. Lloyd (2007), 'Aid and Growth in Kenya: A Time Series Analysis', in Lahiri S. (ed), Theory and Practice of Foreign Aid, Volume 1 of the Series Frontiers of Economics and Globalization, Amsterdam: Elsevier, pp. 313-332

Morrissey, O. and S. Torrance (2015), Aid and Taxation, Chapter 31 in B. M. Avin and B. Lew (eds), Handbook on the Economics of Foreign Aid, Cheltenham: Edward Elgar (forthcoming)

Osei, R., O. Morrissey and T. Lloyd (2005), 'The Fiscal Effects of Aid in Ghana', Journal of International Development, 17(8), 1037-1054

Prichard, W., A. Cobham and A. Goodall (2014), The ICTD Government Revenue Dataset, IDS, Brighton: International Centre for Taxation and Development (ICTD), ICTD Working Paper 19 (www.ictd.ac)

Svensson, J. (2003), Why Conditional Aid Does Not Work and What Can Be Done About It? Journal of Development Economics, 70 (2), 381-402 